\title{
Jantzen and Sedlmayr: Diaphaneia-an impossible presence?
}
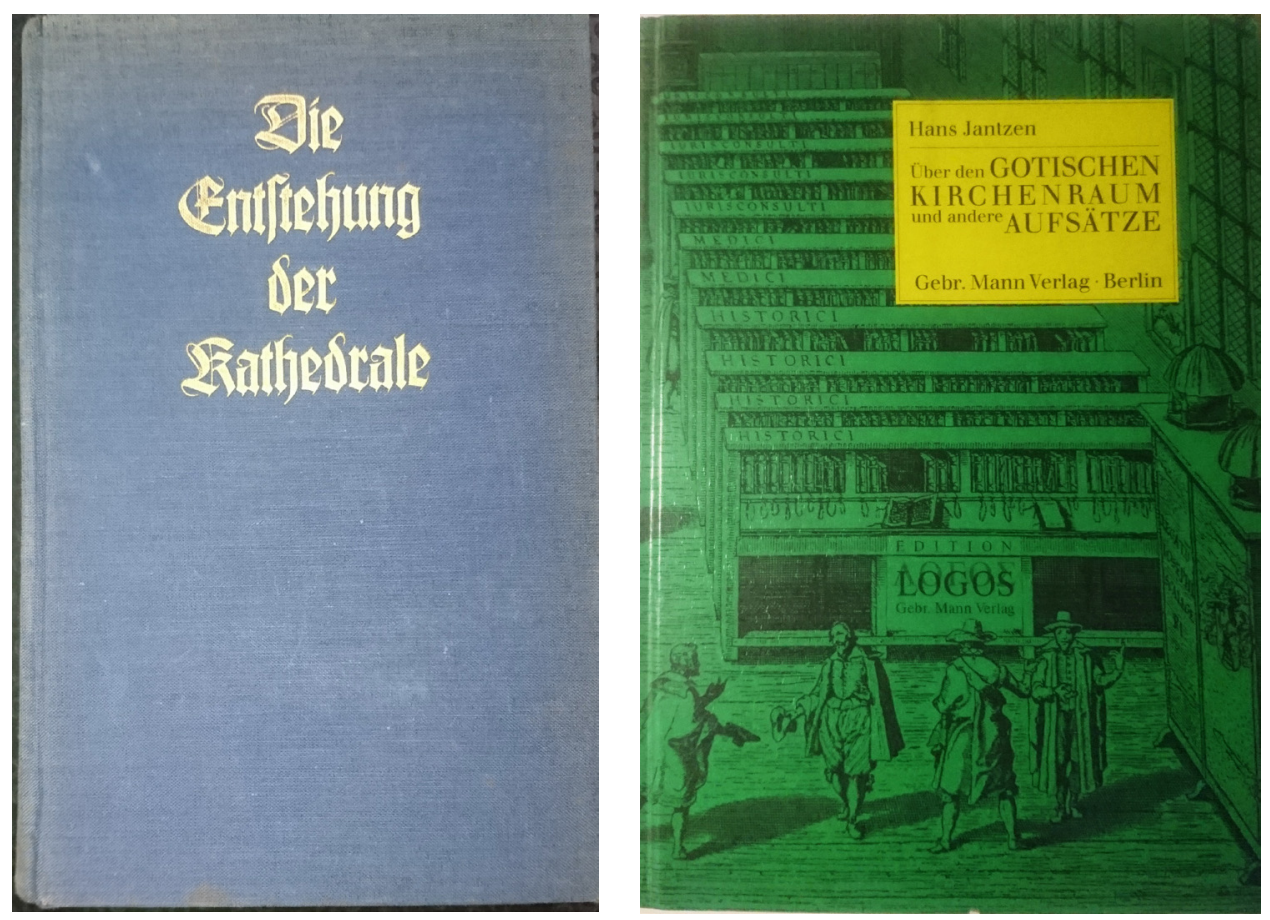

\section{Two texts, one diaphaneity?}

In this article, I would like to consider two texts written by two German art historians: On Gothic Church Space $(1927)^{1}$ by Hans Jantzen and The Origins of the Cathedral $(1951)^{2}$ by Hans Sedlmayr. Both texts, dedicated to the phenomenon of the Gothic, have to do with the notion of diaphaneia, or "diaphaneity". This term, having a long history, was reconsidered by Jantzen and then by Sedlmayr. I propose to trace the logic of the use of diaphaneity by these scholars focussed on the problems of sacred architecture and presence. My suggestion is that, although diaphaneity seems to indicate an impossibility of description and analysis of the transcendent in terms of phenomenology and gestalt-psychology (which may well be a characteristic of the presence and the architecture), it is otherwise a powerful methodological concept and analytical tool, which Sedlmayr complements with the notion of Abbild (depiction). 
Jantzen's On Gothic Church Space, epoch-making in its conscious combination of gestalt psychology and phenomenology, was, albeit subconsciously, used by Sedlmayr in his ambitious project to construct a new architectural history and theory, the monumental The Origins of the Cathedral. The logic behind the interaction of what seem to be but two versions of almost identical conceptual constructs reveals, among other things, the ability of a single word-in this case diaphanous-to indicate two different conceptual configurations that coincide almost nowhere. In this article, I will seek to highlight these configurations and demonstrate that diaphaneity, used to describe the concept of "diaphanous structure" (the term coined by Jantzen), can be seen as an almost universal aspect within a wide variety of contexts.

\section{The history of the term}

Diaphaneity is derived from "diaphanous", so light that you can almost see through it. Although at first sight the concept seems clear, the 'true meanings' that it has taken on in different contexts has been, in fact, far from transparent. This is evidenced by its very history, rooted deep within Aristotelian thought, where two key texts come to the fore, De Anima and De Sensu. The first of these (Chapter II) is particularly important for bringing the concept of transparency ( $\tau$ ò $\delta 1 \alpha \varphi \alpha v \dot{\varepsilon} \zeta)$ already familiar thanks to Pindar and Plato, into almost metaphysical circulation, moreover for doing this through sight and optics.

According to Aristotle, diaphaneity is a quality within things that makes them visible. The question is, are there degrees of diaphaneity and should light be understood as a condition for sight? An even more specific question is the link between diaphaneity and colour, the only thing subject to sight. In the wake of a number of commentators (starting with Alexander of Aphrodisias, who clarified that diaphanous was by no means the same as transparent) we must recognise that diaphaneity is in part linked to surface (i.e. to the permeable or reflective potential of a substance with regard to light). This is already found in the writings of Aristotle (remember that place in De Sensu, 439b 10): "colour is the limit

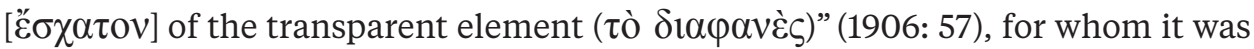
important that diaphaneity makes possible the presence of light in an object (light being above all fire and presence the existence of some active quality, the famous Parousia, which meant that the mystical implications of diaphaneity became obligatory). And vice versa: "Light is the actuality of diaphanousness" (De Anima II 418 / 1907: 79). Of great importance was the filled distance (the intermediary environment and, simultaneously, the medium, or metaxu), in which light can only be manifested: for if we place something coloured on the eye then, as the philosopher of Stagira rightly noted, you do not see the colour (De Anima II 419 / 1907: 79).

The Christian reception of diaphaneity immediately proved eschatological and architectonic, for the sole use of the word in the New Testament (rendered in standard English translates as "transparent") is the celebrated description of the Heavenly Jerusalem ("And the twelve gates were twelve pearls; every several gate was of one pearl: and the street of the city was pure gold, as it were transparent glass" - Revelations, xxi:2 1). Bearing in mind that "gold" in this passage indicates not material but colour, the optics of diaphaneity-both physical and metaphysical-becomes clear. The Medieval reception of diaphaneity lies in its 
Latin morphological transposition, transparentia (used in the twelfth-century Latin translation of Aristotle by Burgundio da Pisa). Thomas Aquinas particularly emphasised that transparency was the equivalent of diaphaneity, moreover, that it was mediality. ${ }^{3}$

If we add to diaphaneity's mediality it is possible to link not only with colour but also with darkness (opacity or impenetrability to light does not mean lack of all visibility), we immediately start to understand the undoubtedly complementary nature of transparency/opacity and their link with the perception of, among other things, artistic creation, something which in its substance (materiality) can be penetrated by the gaze (including the knowing gaze that looks through the object to the ideal) but can also insist on its own corporeality and made-ness. Very early on, transparency became the condition for all penetration, infiltration and mastery, which made it possible in the Renaissance to identify it with perspectiva (the neologism of Boethius, as is well known), and that painted image with the open window (Alberti) or with transparent glass (Leonardo da Vinci).

Thanks to James Joyce's Ulysses (1922), the "diaphane" mentioned by Stephen Dedalus becomes a concept indicating either the emblematics or the hieroglyphics of creation, ${ }^{4}$ while in Le Milieu Divin (1926-1927; published 1957) Teilhard de Chardin gave diaphaneity back its mystical-anagogical context. ${ }^{5}$

\section{Diaphaneity in Jantzen's and Sedlmayr's texts}

All of the contexts outlined above imply different architectures, different spaces, and simply different worlds. ${ }^{6}$ Going back to Jantzen's and Sedlmayr's texts and to the world of church or cathedral respectively, we may note that for them diaphaneity presupposes transcendentality, but with regard to what? Jantzen's answer is space whereas Sedlmayr proposes corporeality. This difference is fundamental: for Jantzen the relationship of body vs background is immutable while Sedlmayr seeks to eliminate the figurative, replacing it with the baldachin (canopy).

For Jantzen, in the middle of his space featuring the layers of body and background, which he describes exclusively in optical and spatial terms, something that seems to belong in a different taxonomy takes place: namely, a liturgical or cultic event (kultisches Geschehen) that presupposes not only the presence of active and passive participants but also transformation: the transubstantiation into the flesh of the Easter Lamb. Sedlmayr, on the contrary, focusses on the baldacchino (the vertical, the weightless) that, he notes, enters the church space from above. Now, for him the relationship is not optical (as they are for Jantzen, for whom light is the "original data"); rather, they are hypnotic, utterly kinaesthetic, and even hallucinatory. The baldacchino's pointing to the heavenly Jerusalem is not merely referential but structural: the architectonic facilitation and equipping of real, active processes, a direct revelation, captured visually and symbolically as an Abbild (depiction). In this regard we might say that Jantzen's concept describes spatial-corporeal states and relationships up to the moment of transubstantiation, while Sedlmayr is more eschatological and in his vision all the relationships are radically altered.

Significantly, for Sedlmayr, in all his texts Abbild is a universal reflection of the state of affairs in the world in general. It is applicable to anything, including Jantzen diaphaneity (which I call here diaphaneity-I), which, in this case, 
is understood as a structure, a relationship of transparency and transitiveness. Later Sedlmayr seems to reveal the metaphorical nature of Jantzen's "diaphanous structure", and thus in The Origins of the Cathedral he proceeds to his own diaphaneity (diaphaneity-II). It appears that, driven by the gestalt of Abbild, he felt obliged to carry out a reduction of 'structure' and saw diaphaneity as a quality, in the phenomenological sense. For him, the bearer of diaphaneity becomes the wall, thus essentially deprived of its corporeality. This way he, so to speak, makes diaphaneity as a structural principle within Gothic disappear: according to his "first wall system", maximum diaphaneity could be found in Justinian architecture.

\section{Das Raumlose (the spaceless)}

Sedlmayr's reduction notwithstanding, the fate of diaphaneity, both its reception and its undoubted apperception, was determined by the meaningful, promising and multi-layered concluding formulations of Jantzen's text. As will be shown, this text is not quite open to straightforward reading, and its semantic tendency and ambiguity seem to be exactly "the design task" out of which Hans Sedlmayr's "church"-both as building and as knowledge-emerged.

The most important thing in Jantzen's text (Jantzen, 2000: 32-33) is undoubtedly the promise of different perspectives. Horizontality set by liberation from space, in which states connected with its disappearance or loss become possible: das Raumlose (the spaceless). Most significantly, they are linked to the enchanting effect on the heart exerted through worship, which is, we must recall, at the centre of all relationships within the church and which is the Mass. This poetic "magic" is comparable to Sedlmayr's "poetic roots of architecture"; but, above all, this is a reaction of the one who reads Jantzen's formula of space: der Raum als Symbol eines Raumlosen (space as a symbol of the spaceless) as an instruction or even as a performative expression (mantra or incantation): one can get rid of space and material and one can rise up if one's heart is subject to and open to influence. Meanwhile, space is allotted a symbolic function, capable of opening up conceptual perspectives, of which Jantzen perhaps never even dreamed.

Our hypothesis is that Sedlmayr, one of Jantzen's most attentive readers, is responsible for "carrying out his will". In that, however, Jantzen himself might have been but a medium, for it is the liturgy which is the source and simultaneously the object of the "testament", if we are to believe, for instance, Otto von Simson in his text The Occidental Testament of the Liturgy (Das Abendländische Vermächtnis der Liturgie), first published around the same year (1945) as Sedlmayr's concept (Simson, 1995). The Mass itself, understood in the medieval synthetic-syncretic spirit as the most active kind of theophany, as a direct discovery of the sacred, has that "power of the image", which we have perhaps ceased to feel and perceive in the modern age, or rather in the post-Tridentine age.

The formula of space as a symbol of the spaceless could easily have been the subtitle of Sedlmayr's The Origins of the Cathedral. We should also note that for the liturgical event, an appropriately constructed space amounts to its 'symbolic form'. The event as such presupposes participation and the impossibility of evasion or detachment, hence the acceptance of this kind of space by the participants as their own state. If this event is a symbol, then for them it is also a means of transcending and overcoming the given state. For us, the implications are as 
follows: if we are consciously talking of symbolic form, notably of space as "the experiencing of edge cases", then it becomes clear that the inevitable, surmounting and transforming interpretation-reaction to any such formula-formulation is exactly this overcoming of present boundary-screens. Jantzen must have known that the expected Raumlose (spaceless) could also take on the form of the baldachin, like any tabernacle-canopy sheltering preserving within all with which it comes into contact. However, it was not he but Sedlmayr who addressed this question explicitly.

Sedlmayr must have realised that the super-formal and, at the same time, deformalising "magic" of the liturgical space required means. Indeed, the arsenal of conceptual formulations such as baldachin, "all-embracing structure", "diaphanous walls" (not "structures") etc. introduced by Sedlmayr under the heading of 'The Phenomenon of the Cathedral' ('Die Phänomene der Kathedrale') are like the instruments of a magus, 'polymath' and enchanter, taking up his stance fully armed to face a challenge, if not a threat, from a comrade-rival very like himself. Or perhaps those were simply precautionary measures as Jantzen, who regularly referred to 'magic' and such like, seemed at once too mystical and magical for Sedlmayr.

\section{The Cathedral: Gestalt and Abbild}

Sedlmayr's most significant conviction and postulate is as follows: the cathedral is, on the phenomenal level, not merely the reproduction of a vision, seen and recorded, of the celestial city, but in its very structure recreates each time the very situation of seeing and meeting. The cathedral is this city, for both are in essence a vision. This happens because the cathedral as gestalt is simultaneously the Abbild (depiction) and leaves nothing else for its viewer and visitor. On one condition, however: that the viewer be not only viewer and not only visitor, but also a participant in that same festivity, that worship, the composition of which includes theophany in the form of the bloodless sacrifice, before which all kinds of visual mysticism recedes but does not disappear, being filled with bare reality, mysticism which is thus relieved of the burden of verticalism: Christ is in the middle, amongst those who have gathered in his name.

We should note that Sedlmayr himself sets this behavioural pattern for his reader, who, it is suggested, should accept the conceptual conditions of what we might call gestalt phenomenology, and should trust the author of the text on the emergence of the cathedral, in order to become a co-author of, as it were, its co-emergence. For Sedlmayr takes seriously Jantzen's proposal-supposition as to those same charms in worship and expands the magic of the constitution of reality.

Sedlmayr's thought was linked to specific liturgics, filled with criticism of the Medieval experience (such is the main spirit of the German "liturgical renaissance"). In the relevant chapters he speaks, without sacrilege, of the theatricalisation of the Mass, points out its choregetic nature (an allusion to Abbot Suger, who compared the service to a dance performance). As we shall see, these postulates intended to play a fundamental role, as well as many other (quite daring, unusual and emphatically provocative) observations on Gothic, set out in the very first chapter, frankly entitled "The Completed Cathedral" (Die ergänzte Kathedrale), which was conceived as a true Gesamtkunstwerk, utterly in the 
spirit of Wagner. It deals with the main function of historical reconstruction: the latter can also be intended as straightforward construction, completion or development of something for which there was no time in the era itself, or which earlier scholarship dared not do. ${ }^{7}$

Such procedures are like the actions of an architect in giving graphic form to their concept using ideographical configurations, preparing their design like a scenario for subsequent actions to be performed by others playing the role of, perhaps, the "builders" of the Gothic cathedral or, for instance, the "priests" carrying out some religious ritual, or even "interpreters" of relevant texts or relevant experiences, in accordance with particular spatial states. ${ }^{8}$

\section{Jantzen's ideas in Sedlmayr's work: the diaphaneity of the space and the diaphaneity of the theory}

Our task, again, is to trace carefully how the direct, clear desire to put into effect Jantzen's ideas about the symbolic aspects of diaphaneity gave birth to Sedlmayr's radically new theory, pregnant with extreme consequences for scholarship. Sedlmayr uses Jantzen for his own ends, which include-among other things-establishing architectural theory as an apparatus for permanent and real transcendence. Essentially, this theory uses representative resources of the architecture, which contains an endless epiphany with its characteristic visual-mystical implications and the potential for departing from any kind of method, according to Gadamer as reported by Hügli and Lübcke (2002). ${ }^{9}$

Significantly, Sedlmayr attempted to found such an important project on the phenomenology not of visual experience (as Jantzen did) but of design-constructive activity. Sedlmayr intended to resurrect the very order and process of the architectonic and, at the same time, of, as it were, prophetic creativity, in which the viewer and user is assigned the role of the performer of the sacramental act, although we must not forget for a moment he who is, was and shall be its creator. As for the architect, they become something along the lines of a choregos and theurge.

The transformed concept of diaphaneity becomes the definitive and decisive point in establishing that presence in the church is the same as presence at revelation, not only apocalyptical and eschatological but absolutely real-timeless and eternal. Thus, revelation is founded, if I may put it this way, on the sacramental concept of the Abbild: the church can itself be the monumental sacramental, like a monstrance-ostensory and baldachin-aedicule, housing within itself and being itself sacred, saved, illuminated and soteriological. ${ }^{10}$

Sedlmayr starts by postulating the incontrovertible abbildende (depictive) nature of the Gothic cathedral, which acts as an individual instance of 'depictive architecture' in general, contrasted to 'symbolic' architecture. The difference between them lies in the degree of realism of that which is represented by the architecture. 'Being-depicted' reality is present at the same level as architecture, while symbolic reality (as is right for any referential relationship) is present beyond the bounds of architecture. In this context the decisive moment is indubitably an understanding of the meaning of depiction.

For Sedlmayr (1976) Abbild is notable for its direct concordance, even convergence, of the signifier and signified: it is far from being mere Bild (which is too 
general a concept), nor is it a symbol; rather it is, to use a term which is not part of Sedlmayr's repertoire, a direct signal. In the Abbild, the sensory converges with the suprasensory. Obviously, for Sedlmayr this is a situation not merely of revelation but rather of visual hallucination. The role of faith in the wider sense in one's value-system is important here: it allows a recognition of the direct link between (even identicality of) the sensory and the suprasensory. Sedlmayr points out that,

in borderline cases, where a depiction is equated with depicted, the need for external resemblance is lowest (Kurz und Kris). It is only "where the belief in the identity of depiction and depicted is waning that a new link between them emerges to bind them: Ähnlichkeit [likeness]". However, when a Sinnbild [symbol, mental image] is considered somehow to resemble the suprasensory, the sinnliche Bild (sensory image) increases in value tremendously (1976: 103).

\section{Abbild and Sinnbild}

In the above text, we note firstly the mention of "borderline cases". For Jantzen, this is in essence where diaphaneity makes its appearance: diaphaneity comes through at the spatial boundary, or rather, space itself is the boundary. Thus, hidden within this quotation from Sedlmayr is reference to that same diaphaneity as transparency which makes the image and that which depicts it mutually penetrable. ${ }^{10}$ Secondly, of course, we note the indication of special cases that require likeness, which is not required in the case of the Abbild, constituted and reinforced by faith. Lastly, it is not difficult to see Sedlmayr attempt to identify (almost by way of pun) meaning and sense: the sensory takes on the meaning and significance (in effect value) of the manifested suprasensory: it proves meaningful, and the sensory image becomes a symbol.

Such reflections are important to Sedlmayr, since his prime purpose is to show how the cathedral becomes and is experienced as the "celestial city", when looked at in a very specific way (we might describe it as assuring discretion and experience of the suprasensory as the sole unifying reality, on a sensory, not only visual, level). The cathedral is not the condition for or means of re-experiencing revelation (both as apocalypse and as epiphany) but is itself the situation of epiphany-theophany. Suffice it to say that this situation is liturgical and Eucharistic, presuming both presence and communion with the presence. Sedlmayr is quite open here (chapter 27 and after). It is important for him to apply maximum method and methodology to justify what we have already called religious-mysterious experience, to show that this is a matter not of metaphor, but of reality. To be precise, Sedlmayr's task is to resurrect the experience (both mystical and architectonic) of those responsible for creating the cathedrals, and perhaps to repeat it.

Sedlmayr's conceptual equipment (phenomenology and gestalt theory) allowed him to do this: one can, again almost on a sensory level, make clear, comprehensible and acceptable the idea that the true Abbild is capable of many things, one of which is that it facilitates the unquestioned intentional unity of the earthly and heavenly, by very reason of architecture's involvement. ${ }^{12}$

Such a conceptual form-factor is facilitated by diaphaneity in the sense given it 
by Jantzen. Architecture as such-or its space-is diaphanous, and its extremes and polar opposites come through. They come through, come together and unite for the sake of something new, something which might be that very same boundary, or it might be tensions, dissonance and disruption: for gestalt laws of grouping within the psyche also offer a group of pre-mimetic and pre-figurative states that are, essentially, moods (see below).

It is important to understand that the very relationships between these concepts and their authors are diaphanous: Jantzen is the "ground" for Sedlmayr's new "figurativity" (in gestalt terms) but he also pervades it. Whole theoretical systems and books are capable of being symbolic forms, not only of both the spaceless and also deprived of space (Jantzen's Raumloses).

\section{Diaphaneity: the hermeneutics of the impossible?}

How can that deprived of space, that free of our sensory perception, become an object of representation? Perhaps new light needs to be thrown upon it, there needs to be a new sacramentalisation of the renewed mystery? Or do we need to move into other spheres and discourses, notably epistemological? This is the tactic-unconsciously, it seems to us-chosen by Sedlmayr. For, as he speculated, there was surely a good reason why, for example, the illumination of the church became such an obligatory element at a very particular point in liturgical development. Sedlmayr might have felt forced to turn to this ritual, this religious action-ceremony, to explain his intuition regarding the means for, or rather the quality of, the presence of the Heavenly Jerusalem. That same logic lies within the desire to affirm Abbildlichkeit, depiction through references to the word, to literacy, to poetic texts: these are not simply verifiable "written sources". It is not simply the recording of speech, but its essential clarity, free of representation, something close to expression in its similarly essential import and significance as an unmediated stamp or trace, the Abbild, evident and physiognomical, as a reciprocal impulse, a reaction to impression and expression (Eindruck and Ausdruck). And the act of writing is that same ostensive gesture, although deprived of the precision of the dot: it is, rather, a spot (macchia) or punctum, a touch, whether of the gaze or the finger (the latter comes to our aid when the first comes across its own blind spot). ${ }^{13}$

In conclusion, let me emphasise the most important hermeneutic aspect of the transition from diaphaneity-I to diaphaneity-II, in which Sedlmayr's twice-repeated phrase "Ich komme zum Schluss" ("I am coming to the end") is of the essence. Temporality is perhaps the most decisive-eschatological-instrument in interpreting diaphaneity. This ending or conclusion is like some exclusion-enclosure, exhaustion and completion of the world's structurality, being the same transition from Bild (picture) to Abbild (depiction), from sight to hearing, and from diaphaneity (Diaphaniea) to Derrida's 'diaphony' (Diaphonie). This forces us to listen to the Stimme (voice), and through Stimmung (mood) move on to Bestimmung (definition). ${ }^{14}$

Thus, signifying the presence of the transcendent in the space of liturgical experience (Jantzen: year?), diaphaneity, at the same time, points at that which is behind it, which negates space and turns out to be body and then text. Sedlmayr's subconscious, as I believe, correction of Jantzen seems to teach us a hermeneutic lesson: it is impossible to catch the presence in either 


\section{space-phenomenal-sacramental or mental-textual.}

In further research, it could be interesting to address more emerging questions concerning connections between the optical and textual: on what condition can architecture remain "sacred", providing the presence of the transcendent? What other kinds of diaphaneity seem possible here- of affect? of empathy? of consciousness? But unfortunately, I should stop here.

REFERENCES

Aristotle. (1906). De Sensu and De Memoria: Ross, G. R. T. (Ed.) Text and translation with introduction and commentary. Cambridge, UK: Cambridge University Press.

Aristotle, Hicks, R. D. (Ed.) (1907). Aristotle De Anima; With translation, introduction and notes (R. D. Hicks, Trans.) Cambridge UK: Cambridge University Press.

Böhme, G. (1995). Atmosphäre: Essays zur neuen Ästhetik. Frankfurt am Main: Suhrkamp.

Böhme, G. (2014). The theory of atmospheres and its applications. Trans. A.-Chr. Engels-Schwarzpaul, Interstices 15 Atmospheres and Affect, pp.92-99.

Böhme, G., \& EngelsSchwarzpaul, A.-Chr. (Ed.) (2017). Atmospheric architectures: The aesthetics of felt spaces (A.-Chr. Engels-Schwarzpaul, Trans.). London, UK: Bloomsbury Academic.

Derrida, J. (2011). Voice and Phenomenon: introduction to the problem of the sign in Husserl's phenomenology, trans. Leonard Lawlor,Evanston, III. : Northwestern University Press.

Gantner, J. (1979) «Das Bild des Herzens». Über Vollendung und Un-Vollendung in dr Kunst. Reden und Aufsätze. Berlin: Gebr. Mann.
Gumbrecht, H.G. (2004).

Production of Presence: What

Meaning Cannot Convey.

Standford (Cal.): Stanford

University Press.

Heidegger, M. (1996). Being and time, trans. J. Stambaugh, Albany, NY: State University of New York.

Hügli, A., Lübcke, P.

(2002). Philosophie im

20. Jahrhundert. Band I:

Phänomenologie, Hermeneutik,

Existenzphilosophie und kritische

Theorie. Hamburg: Rowohlt.

Jantzen, H. (1984). High Gothic.

The Classic Cathedrals of

Chartres, Reims, Amiens, tr.

James Palmes, Princeton:

Princeton University Press

[originally (1957) Die Kunst der

Gotik. Hamburg: Rowohlt].

Jantzen, H. (1997) Die Gotik des Abendlandes. Köln: N. DuMont Schauberg.

Jantzen, H. (2000). Über

den gotischen Kirchenraum und andere Aufsätze, Berlin: Mann [originally Freiburger Wissenschaftliche Gesellschaft, Heft 15, Freiburg in Breisgau, 1928].

Jormakka, K. (2006). Geschichte der Architekturtheorie. Vienna: Luftschacht.

Maas, R. (2015). Diaphan und gedichtet: Der künstlerische Raum bei Martin Heidegger und Hans Jantzen. Kassel: Kassel University Press.

Pfisterer, U. (ed.) (2011). Metzler Lexikon der Kunstwissenschaft. Stuttgart: J.B. Metzler Verlag.
Nille, C. (2013). Mittelalterliche Sakralarchitektur interpretieren. Eine Einführung. Darmstadt: Wissenschaftliche Buchgesellschaft.

Paumann, L. (2010). Vom Offenen in der Architektur. Vienna: Passagen Verlag.

Sauerländer, W. (1997). Hans Jantzen als Deuter des gotischen Kirchenraumes. Versuch eines Nachworts. In: Hans Jantzen: Die Gotik des Abendlandes (pp. 210218). Köln: N. DuMont Schauberg.

Schmarsow, A. (1998).

Grundbegriffe der

Kunstwissenschaft: Am Übergang vom Altertum zum Mittelalter [1905]. Berlin: Gebr. Mann.

Sedlmayr, H. (1976). Die

Entstehung der Kathedrale, Munich: Atlantis-Verlag; 3rd edn., Freiburg: Herder.

Sedlmayr, H. (1939). Die

Architektur Borrominis, 2nd edn, Munich: Piper.

Simson, O. von (1995) „Das Abendländische Vermächtnis der Liturgie". In Von der Macht der Bilder im Mittelalter. Gesammelte Aufsätze zur Kunst des Mittelalters. 2nd ed. Berlin: Gebr. Mann.

Summerson, J. (1963). Heavenly Mansions and Other Essays on Architecture, New York: W. W. Norton.

Teilhard de Chardin, P. (2001). The divine milieu: An essay on the interior life, New York, NY: Harper \& Row.
Vesely, D. (2004) Architecture in the age of divided representation. Cambridge, MA: MIT Press.

Wittgenstein, L. (1922). Tractatus logico-philosophicus. Logischphilosophische Abhandlung. Side-by-side edition containing the original German, alongside both the Ogden/Ramsey, and Pears/McGuinness English translations. Retrieved from http:// people.umass.edu/klement/tlp/ tlp.epub 


\section{ENDNOTES}

\section{Jantzen 2000: 7-34.}

2 Hans Sedlmayr, Die Entstehung der Kathedrale, Munich: AnlantisVerlag, 1951; 3rd edn, Freiburg: Herder, 1976.

3 "Huiusmodi corpora proprie dicuntur perspicua sive

transparentia, vel diaphana. Phanon enim in Graeco idem est quod visibile..." Thomas Aquinas, Sentencia libri De Sensu et sensatur, Lect. 6. their being coloured... Limit of the
4 Limits of the diaphane. But he adds: in bodies. Then he was aware of them as bodies before of diaphane in. Why in? Diaphane, adiaphane." The phrase 'maestro di color che sanno' in this section is also a reference to Aristotle, but as he appears in Dante's Inferno (IV 131).

5 XVII.4.3: 'Yes, Lord, not only the ray that strikes the surface, but the ray that penetrates, not only your Epiphany, Jesus, but your diaphaneity.' (Chardin 1960: 130-131). And Jantzen himself includes a quotation from Teilhard: Jantzen 1997: 40. But such diaphaneity is more typical of Neo-Platonism (particularly medieval) than of Aristotelianism. Compare, therefore: '...Luminosity can be described as a theophany of light (Iux), which penetrates the world and moves hierarchically through the different levels of reality (Vesely, 2004: 116).

6 A full and extremely precise history of the concept is set out in: Maas 2015: 124ff. (particularly the relationship between Aristotle on one hand and Heidegger and Jantzen on the other, covering the various implications and individuals involved).

7 Recall the spirit of Sedlmayr's pre-war texts regarding "strict science" in the arts, where the leitmotiv is "non-Euclidian" methodology, although applied to Baroque material, which is nonetheless not so far removed from Gothic. See, for instance: Sedlmayr, 1939.

8 On mystical connotations of the method (mystische Konnotationen der Methode) and axonometric projection as a form of presence, see: Jormakka (2006: 205).
9 Cf:: "'Gadamer's intention is not to develop a methodology that would help us reach a 'more correct' interpretation or exegesis but to point out the - transcendental - elements presumed in any interpretation, whether we like it or not" (Hügli \& Lübcke, 2002: 209).

$10 \mathrm{~A}$ superb example of the universal reading of the aedicule motif (using Gothic as an example) is John Summerson's essay [Summerson 1963].

11 See Wittgenstein (1922): "2.16 Die Tatsache muss, um Bild zu sein, etwas mit dem Abgebildeten gemeinsam haben. [...] 2.171 Das Bild kann jede Wirklichkeit abbilden, deren Form es hat. Das räumliche Bild alles Räumliche, das farbige alles Farbige, etc. (2.16 "In order to be a picture a fact must have something in common with what it pictures. [...] 2.171 The picture can represent every reality whose form it has. The spatial picture, everything spatial, the coloured, everything coloured, etc." Cf. later: 2.172 "Seine Form der Abbildung aber, kann das Bild nicht abbilden; es weist sie auf." "'The picture, however, cannot represent its form of representation; it shows it forth.").

12 And simply the cathedral as monumental mystery (Kathedrale als monumentales Mysterium), which we find in Jantzen (see: Mass, Op. cit.: 151), who perceived the mystery of gothic space phenomenologically (das Mysterium des gotischen Raumes phänomologisch erfaßte) (Sauerländer, 1997: 213). The "revealed" is also a mystery understood as a duration in the unlimited time of the Aion (die Dauer in der unbeschränkten Zeit der Aion) (Paumann, 2010: 111 with reference to Deleuze). She adds that it is the inspirational, virtual side of reality that shines through form ("Was durch die Form hindurchleuchtet, ist die inspirative, virtuelle Seite der Realität", Ibid.: 112. But we must always recall the danger of fetishisation of architecture as such (Paumann, 2010: 62-64).

12 "Macchia" is one of the fundamental concepts in Sedlmayr's system of views (but not only his - see also, for instance, Joseph Gantner and his "prefiguration" (1979: 107-136).
13 We should recall the fundamental and at the same monumental pre-history of this "spots", not just optical but haptic: Alois Riegl with his idea of "haptic form" as the result of primal tactile experience (touching a surface with our fingertips shapes our understanding of twodimensionality, which thus unfolds in space as the sum of many dots), and August Schmarsow, with his key correction to Riegl's idea, asserting the impossibility of drawing tactile or bodily experience from touching individual points alone and suggesting instead an experience of holistically and kinaesthetically experienced somatics, including the whole and living body. See: Schmarsow, 1998: 42.

14 Cf. for instance: "Die Stimme... ist nämlich die Artikulation leiblicher Anwesenheit" ("In fact, voice is an articulation of bodily presence", Böhme, 1995: 146). Cf. Böhme 2014. And, undoubtedly, Jacques Derrida, who, in Voice and Phenomenon spoke, among other things, of "the instance of voice and its strange authority" (Derrida, 2011: 60).. Cf. also: Gumbrecht 2004, especially the chapter: "Epiphany/ Presentification/Deixis: Futures for the Humanities and Arts". 